\title{
Literackie wizje ogrodu księżnej Izabeli Czartoryskiej na przykładzie semantyki uczuć - romantyczna percepcja poety wędrowca
}

Problematyka ogrodowa to częsty motyw pojawiający się w literaturze i kulturze różnych epok. Zainteresowanie wzbudzała nie tylko sama jego przestrzeń i założenia architektoniczne. Dość często zwracano uwagę na otaczającą szatę roślinną czy charakterystyczne budowle. Jednak zawsze upatrywano w nim koncepcji boskiego Raju i tęsknoty za tym, co „naturalistyczne” i prawdziwe ${ }^{1}$. Ogród symbolizował również mistyczną ekstazę i tajemnicę duszy. Odwoływał się w swym znaczeniu do medytacji, kontemplacji, jak również świadomości ${ }^{2}$. Utożsamiany był ponadto z ziemskim rajem, miejscem zamieszkania pierwszych ludzi, a wyodrębniony boską lub ludzką ręką, stał się oazą bezpieczeństwa i szczęścia ${ }^{3}$. Nasuwa się stwierdzenie, iż zakładane ogrody miały uosabiać właśnie ów utracony raj i poprzez swoją ukrytą symbolikę nawiązywać do niego. Znaczenie owego krajobrazu określał także kształt i rozplanowanie ogrodu 4 . Tym samym doszukiwano się w nim poetyckich inspiracji oraz poszukiwano idei piękna ukrytego w ogrodowej scenerii. Podobnie twierdziła Joanna Maleszyńska, według której ogród poprzez swoje właściwości stawał się tekstem kultury, a jego symbolika

1 J. Lileyko, Pałac i ogród. Natura zawtaszczona przez sztukę, ,Biuletyn Historii Sztuki” LXIII, 2001, nr 1-4, s. 32.

2 W. Kopaliński, Ogród, [w:] idem, Stownik symboli, Warszawa 2006, s. 269.

3 J. Pelc, Ogrody jako miejsca szczęśliwe, „Barok. Historia — Literatura — Sztuka” IV, 1997, nr 1, s. 7.

4 J.E. Cirlot. Ogród, [w:] idem, Stownik symboli, Kraków 2000, s. 283. 
zakodowana w świadomości kulturowej oraz ukształtowanie krajobrazu „zdeterminowały właściwości odpowiednich utworów literackich"5.

Piszący o ogrodach odwoływali się przede wszystkim do idei piękna, natomiast człowiek otoczony niczym nieskrępowaną naturą szukał w niej czegoś w rodzaju axis mundi, czyli osi świata. Już literacko-renesansowa wizja ogrodów, jak zauważał Jerzy Lileyko, pobudzała wrażliwość na postrzeganie natury, która współtworzyła kulturę oraz określała pewien styl życia ${ }^{6}$. Literackie koncepcje ogrodu były także „próbą stworzenia ziemskiego Raju, a jednocześnie „obłaskawienia" natury, generalnie postrzeganej jako mało przyjazna ludziom" ". Podobnie myśleli twórcy u progu romantyzmu, szukając w naturze boskiego pierwiastka utraconego Edenu. Jednak zaczęto zwracać uwagę na samą naturę, nieujarzmioną, dziką i tajemniczą, która stawała się również przyjacielem poety-obserwatora.

Motyw ogrodu pojawiał się często w twórczości poetów puławskich, którzy zafascynowani parkiem Izabeli Czartoryskiej, opisywali otaczającą ich naturę. Zachwycała nie tylko jego romantyczna wersja czy budowle parkowe. Przedmiotem zainteresowania stały się również rzadkie gatunki drzew i kwiatów. Ogród był sztuką tworzenia, czerpiącą inspirację właśnie z samej siebie. Był sztuką samą w sobie. Ogrody romantyczne w odróżnieniu od klasycystycznych, w których panowała niezmienność i bezruch, wyróżniały się swą kompozycją i ukształtowaniem, gdzie ogromną rolę odgrywał także zwiedzający ów ogród. Jak mówi Lichaczow:

Ogród romantyczny jest kategorią w wiecznym stawaniu się. Ogród jest percypowany w procesie swojego rozwijania się i kiedy to człowiek przenika weń w trakcie spaceru, włącza się w jego atmosferę i nastrój ideowy. Ogród rozwija się w czasie poprzez zmiany dobowe pór roku, zmiany pogody, a także w miarę pojawienia się w nim coraz to nowych pamiątek ${ }^{8}$.

W istocie park księżnej Izabeli został stworzony jako powielenie naturalnego krajobrazu, jednak jego specyfika pozwalała wyrażać artyście swój stosunek do otaczającej go przyrody za pomocą utrwalonych w kanonie literackim symboli i archetypów. Jeżeli ogród był sztuką, to artysta, który w nim tworzył, stawał się twórcą doskonałym przelewającym tę sztukę na papier. Park był również miejscem zabaw i przeróżnych spotkań towarzyskich ${ }^{9}$. Jak zauważyła Alina Aleksandrowicz, „był częścią dworu, wyjściem w naturę, w nowy obszar egzystencji,

5 J. Maleszyńska, Staropolskie ogrody literackie. Między topika a genologia, ,Pamiętnik Literacki" LXXV, 1994, z. 1, s. 12.

6 J. Lileyko, op. cit., s. 29.

7 Ibidem, s. 30.

8 D. Lichaczow, Poezja ogrodów. O semantyce stylów ogrodowo-parkowych, Warszawa 1991, s. 263.

${ }^{9}$ O rodzajach zabaw w puławskim parku między innymi: A.A. Witusik, Rzecz o zabawach na dworze puławskim, [w:] idem, Z raptularza historyka, Lublin 1982, s. 340-343; J. Skiba, Homo ludens pulaviensis, „Teka Puławska” 1988; G. Bartnik, Zabawy na dworze puławskim, „Kwartalnik Powiatu Puławskiego. Tu Jest Moje Miejsce" 2011, nr 7, s. 24-27. 
odrzuceniem pozoru, wybraniem zaś istoty"10. Stawał się też miejscem, gdzie artysta mógł swobodnie czerpać inspirację z otaczającej go przyrody. Pozostawiona spuścizna stała się materiałem do analizy patrzenia na ogród puławski przez pryzmat przebywającego $\mathrm{w}$ nim poety. W prezentowanych rozważaniach interesować nas będzie ogród jako symbol kultury, jako pewien system znaków - natura naturans - które człowiek powinien starać się rozszyfrować ${ }^{11}$. W tym miejscu powołamy się również na koncepcję Dimitrija Lichaczowa zakładającą, iż ogród-nadawca to pewien rodzaj symboli, natomiast przebywający w nim to odbiorca, który te składniki odczytuje ${ }^{12}$.

Jednym z pierwszych piewców Puław był czołowy przedstawiciel sentymentalizmu puławskiego Franciszek Dionizy Kniaźnin. Poeta w swoich utworach między innymi Balon, Dwie gałąki, Dwie lipy odwoływał się również do otaczającej go przyrody. Przedmiotem rozważań są dzieła nieco późniejsze, aczkolwiek zasługujące na uznanie, jak na przykład poemat Puławy Juliana Ursyna Niemcewicza ${ }^{13}$, Erinnerung an Puławy ${ }^{14}$ Eugena von Gutschmidta, urywek z Ogrodów Jacques'a Delille'a ${ }^{15}$ czy fragment wiersza Ogród w Puławach ${ }^{16}$ bibliotekarza Czartoryskich, Karola Sienkiewicza. Punkt wyjścia w niniejszych rozważaniach stanowi również rozprawa Dimitrija Lichaczowa Poezja ogrodów ${ }^{17}$. Tematyka, która będzie nas interesować, dotyczy symboliki ogrodu związanej z przechadzką, doznaniami zmysłowymi, jakie weń występują, i oddziaływaniem na odbiorcę. Nasuwa się tym samym stwierdzenie, iż kierunek wędrówki krystalizowany był przez składniki ogrodowej przestrzeni, gdzie również można było oddać się przyjemności melancholijnej ${ }^{18}$, wątek przechadzki stał się wyznacznikiem ogrodowej literatury okresu przełomu oświeceniowo-romantycznego, w której doniosłe znaczenie miała samotna wędrówka.

Romantyczny obraz puławskiego parku uchwycił najpełniej Julian Ursyn Niemcewicz w poemacie Puławy, napisanym około $1804 \mathrm{roku}^{19}$. Poeta wychwala

${ }^{10}$ A. Aleksandrowicz, Ogród puławski jako teren inspiracji kulturowych. Z problematyki kultu drzew, [w:] Dwory magnackie w XVIII wieku. Rola i znaczenie kulturowe, red. T. Kostkiewiczowa, A. Roćko, Warszawa 2005, s. 137.

11 R. Przybylski, Ogrody romantyków, Kraków 1978, s. 25. Przybylski powołuje się w swoim opracowaniu na tezy postawione przez Maurycego Mochnackiego.

12 D. Lichaczow, op. cit., s.187.

13 J.U. Niemcewicz, Puławy. Poemat w czterech pieśniach, wyd. i objaśnił J. Kallenbach, Brody 1907.

${ }^{14} \mathrm{~W}$ tym miejscu korzystamy z polskiego thumaczenia: E. Gutschmidt, Wspomnienia z Puław, przeł. T. Arasimowicz, Puławy 2005. Pierwodruk oryginału: Erinnerungen an Pulawy, Leipzig 1828.

15 J. Delille, Les jardins, Paris 1813.

16 K. Sienkiewicz, Ogród w Puławach, [w:] Polihymnia czyli piękności poezyj autorów tegoczesnych dla miłośników literatury polskiej, wyd. J. Szczepański, t. 3, Lwów 1827.

17 D. Lichaczow, op. cit.

18 M. Cieński, Przyjemności parkowe i ogrodowe w życiu i literaturze polskich oświeconych, [w:] Przyjemność w kulturze epoki rozumu, red. T. Kostkiewiczowa, Warszawa 2011, s. 62.

19 J.U. Niemcewicz, Pamiętniki czasów moich, wyd. J. Dihm, t. 2, Warszawa 1957, s. 234. 
w nim piękno puławskiego parku, przedstawiając go niczym impresjonista o różnych porach dnia. Podzielony na cztery pieśni poemat opiewał uroki puławskiego parku i był wyrazem czci dla chlebodawców jego autora. Pieśń pierwszą rozpoczyna przedstawieniem poranka, pieśń drugą — południa, by w pieśni trzeciej opisać ogród w porze wieczornej, w czwartej zaś przedstawić park puławski nocą ${ }^{20}$.

Los mnie przez fale przeniósłszy pieniste,

Raz jeszcze widzieć dał ziemię ojczyste; [...]

Tysiąc obrazów w mym umyśle staje,

I wdzięczność i przyjaźń lutnię mi podaje,

I każe nucić przyjemne Puławy,

I ich mieszkańców czyny i zabawy (I, w. 5-12).

Powrót do Ojczyzny zaowocował wspaniałym poematem opisującym nie tylko codzienne zajęcia domowników, park o różnych porach dnia, lecz także roślinność, występującą w ogrodzie księżnej Izabeli. Poeci przebywający w parku mogli odnaleźć inspirację do swoich utworów. „Luby ustroń” okazał się azylem, miejscem, gdzie można na chwilę siąść, odpocząć i zachwycić się otaczającym widokiem. Niemcewicz, przechadzając się po parku, wymienia szereg miejsc odwiedzanych, które mimo iż nie są umiejscowione w odpowiedniej przestrzeni, to wpływają na jego doznania emocjonalne. Poeta wylicza składniki krajobrazu, które wpływają na jego twórczość. Być może jest to początek myślenia romantycznego, gdyż jak zauważyła Łucja Ginkowa, typowym zjawiskiem dla liryki przedromantycznej było „komponowanie pejzażu przez wyliczanie jego składników najczęściej nie zlokalizowanych przestrzennie"21. Tak oto podmiot liryczny Puław wymienia „luby ustroń,, „czyste zdroje” i „,posępne góry”. Przytoczmy fragment poematu Niemcewicza mówiący o tym zjawisku:

Luby ustroń, gdzie gajów świeżość, wód szemranie

Wabi oczy i słodkie wzbudza zadumanie,

Te groty, czyste zdroje, te posępne góry,

Nie dziełem sztuki - wszystkie są tworem natury;

Wszędzie wiejskie obrazy! (I, w. 615-620)

Percypowany przez podmiot liryczny krajobraz podkreśla zatem związek człowieka z naturą, która staje się dla poety najważniejszą częścią kontemplacji. Nasuwa się stwierdzenie, iż można dostrzec w przytoczonym niżej opisie cechy sentymentalnej liryki krajobrazowej, gdzie „Człowiek czuły, konkretyzowany

20 Temat nocnego ogrodu puławskiego został poruszony w pracy: G. Bartnik, , [...] idę rozrzewniony/ Gtuchej i ciemnej nocy czucia me powierzyć" — literackie wizje nocnego Ogrodu Putawskiego jako zapowiedź przełomu romantycznego, [w:] Noce romantyków. Literatura - kultura - obyczaj, red. A. Rej, D. Skiba, M. Ursel, Kraków 2015.

21 Ł. Ginkowa, Cechy języka sentymentalnej $i$ wczesnoromantycznej liryki krajobrazowej, „Pamiętnik Literacki” LXIX, 1978, z. 4, s. 198. 
jako podmiot lirycznej wypowiedzi analizował i wyrażał przede wszystkim własną osobowość, świat uczuć i przeżyć"22.

I kolejny fragment:

Ach! Jak dziś słodko umysł mój zajęty

Lubym i zarazem wspaniałym widokiem.

Gdziekolwiek chciwym w koło rzucę okiem,

Wszystko mym czuciom pokarmu udziela,

Zachwyca, smuci, kwili, rozwesela (I, w. 114-118)

Symbolika ogrodowa koncentrowała się również wokół praktyki pamięci. Obok podziwianych kwiatów i drzew, do głosu zaczął dochodzić memorialno-emblematyczny wymiar parku ${ }^{23}$. U progu romantyzmu symbolika ta nabiera znaczenia przez zwrócenie uwagi na osobiste uczucia oglądających. Tak oto w parkach doby romantyzmu skojarzenia budziły rozmieszczone w gęstwinie krzewów i kwiatów czy umieszczone pod drzewem pamiątkowe głazy, tabliczki z inskrypcją poświęcone komuś lub czemuś. Lichaczow w swojej rozprawie zwraca uwagę, iż to uczucia wędrowca przeważają i zmieniają znaczeniowość wspomnianych emblematów ${ }^{24}$. Wspomniana symbolika została zaplanowana i dopracowana przez samą Czartoryską. Autorka monumentalnej pracy Myśli różne o sposobie zakładania ogrodów w rozdziale poświęconym „monumentom” wyjaśnia pokrótce owo założenie.

Takowe pamiątki trzeba uwdzięczać Milczeniem, Tajemnicą, Ciekawością i chęcią znalezienia ich albo Zadziwieniem, kto o nich wie. Ieżeli te pamiątki są smutne, niech ten, który ie odkrywa w ciemnym Gaiku lub na ustroniu w zakątku cichym, niech, mówię, spocznie oczom swoim, patrząc na nie bez przerywania i roztargnienia; niech w tem miejscu nie przeszkadzają mu inne widoki ${ }^{25}$.

Napisy nie mają być „płonne”, lecz „są miłe, kiedy są trafne, krótkie i rzadkie" ${ }^{26}$. Krótko i zwięźle sprecyzowane założenia ogrodowe dotyczące „monumentów" podkreślały ideę percepcji wzroku. Tym samym przechadzający się po ogrodzie odbierał ogrodową symbolikę jako zespół znaków, które przypominały mu chociażby o przemijalności czasu i ulotności ludzkiego życia. Niemcewicz w pieśni III zapisze:

Ilekroć zamyślony błędne widząc kroki [...]

Krętą ścieżką do krytej i tajnej ustroni,

Tajnej — bo i zapłakać ciężka przemoc broni'

Ujrzałby skryty bluszczem i smutnym cyprysem

Głaz prosto uciosany z tym tkliwym napisem:

„Tym, co polegli broniąc kochanej Ojczyzny” (III, w. 527-538).

Natomiast w pieśni IV:

22 Ibidem, s. 186-187.

23 D. Lichaczow, op. cit., s. 209.

24 Ibidem, s. 210.

25 I. Czartoryska, Myśli różne o sposobie zakładania ogrodów, Wrocław 1805, s. 52.

26 Ibidem, s. 54. 
Tam się pomnik przeszłości podnosi od ziemi,

Nieszczęsny Polak łzami zlewa go rzewnemi.

Omylony promieniem nadziei zwodniczym,

Przeszłość dla niego wszystkim, a przyszłość już niczym (IV, w. 905-908).

W przytoczonym fragmencie wspomnienie dawnych zwycięstw daje siłę „Zwodniczej nadziei”, że wolność utracona wraz z przeszłością minęła bezpowrotnie. Przeszłość można kultywować tylko samotnie — w postaci chwili refleksji i zadumy nad tym, co minione. Należy ją utrwalić nie tylko pamiątkowym głazem czy inskrypcją. Praktyka pamięci powinna być poparta również „słowem” poety ogrodnika odczytującego sens znaczeń i wplatającego „słowo” w przestrzeń literacką. Rozważając w tym miejscu słowa Lichaczowa, powinniśmy powtórzyć jego założenie stanowiące jakby sens założeń samotnej wędrówki. Otóż badacz skłania się ku refleksji, że samotność w parkach doby romantyzmu stała się celem filozoficznego wgłębiania w sens przyrody ${ }^{27}$. Rozszerzając zaś jego teorię, należałoby w tym miejscu przyjrzeć się bliżej tym komponentom parku, które odwołują się do znaczenia emblematyki. Możemy również założyć, iż jest to wgłębianie się w jej sens. Memorialno-emblematyczny symbol parku to również jego polisemantyczność. Nie tylko gra słowa, jego wizualność, lecz także jego znaczenie. Śmiało można stwierdzić, iż piewcy puławskich ogrodów dostrzegali charakter założeń i koncepcji Czartoryskiej, która zakładała odczytywanie pewnych znaczeń i skojarzeń w oparciu o ,słowo" 28 .

Puławscy poeci dostrzegali w parku również element Raju, miejsca, gdzie na łonie natury można w spokoju i ciszy oddać się kontemplacji lub po prostu odpocząć. Natura sprawiała, iż przebywający w nim artysta doznawał wielorakich przeżyć emocjonalnych, które poniekąd stały się inspiracją do powstałych tekstów. Dla jednych park puławski był „lubym ustroniem”, inni natomiast porównywali Puławy do „łąk Elizjum”, „,szczęśliwej Walhalii”, „partenopejskiej zatoki” czy „starożytnych wysp szczęśliwych”29. Przytoczone porównania należą

27 D. Lichaczow, op. cit., s. 210.

28 Należałoby bliżej przyjrzeć się koncepcjom Czartoryskiej, zawartym w Myślach różnych..., oraz rozszerzyć tematykę badań o symbolikę słowa, również w oparciu o założenia D. Lichaczowa, mówiące o memorialno-emblematycznym symbolu parku. Przestudiowania wymaga też kategoria ogrodowej praktyki pamięci.

29 E. Gutschmidt, op. cit., s. 19-21. Poemat zdobył uznanie wśród krytyki literackiej. Jedną z recenzji zamieszczono w czasopiśmie „Pamiętnik Umiejętności Moralnych i Literatury”: „Dziełko poświęcone księżnej Czartoryskiej generałowej ziem podolskich i księżnie Wirtemberskiej, zawierających 26 poetycznych opisów Puław i czarujących ich okolic, ozdobione 24 ładnymi widokami. Należy do kosztownych wydań. Na początku opisów znajdują się stosowne godła w językach: niemieckim, angielskim, francuskim, włoskim, a nawet arabskim. Autorem dzieła jest młody Sas. Powodem do napisania go był mu znaleziony grób jego ojca, który podczas ostatniej kampanii francuskiej do Moskwy, umarł w Puławach i tam na cmentarzu ewangelickim jest pochowany. Miłość synowska wzniosła tam jego pomnik i uświetniła miejsce natchnieniem poetycznem. Ileż to wspomnień do tego Panteonu polskiego rodacy i cudzoziemcy nie przywiązują”. „Pamiętnik Umiejętności Moralnych i Literatury” 3, 1830. 
do barona Gutschmidta, który dowiedziawszy się o śmierci ojca ${ }^{30}$, postanawia odwiedzić kraj Sarmatów. Przyjazd do Puław zaowocował powstaniem wspaniałego dzieła Erinnerungen an Pulawy opisującego widoki zarówno parku, jak i całej okolicy. Poemat powstał najprawdopodobniej jako wdzięczność za należyty pochówek zmarłego. Utwór opatrzony został dedykacją poświęconą Izabeli Czartoryskiej oraz jej córce Marii z Czartoryskich Wirtemberskiej. Poeta, niczym wieczny tułacz, eksponuje emocjonalne przeżycia, jakie wywołuje w nim otaczający go krajobraz. Autor Wspomnień z Puław porównuje siebie do pielgrzyma, który odbywa podróż do „dalekich krajów” w celu oddania czci zmarłemu ojcu. Z pieczołowitością opisuje każdy zakątek parku, otaczające go krajobrazy oraz budowle parkowe. Można wysunąć stwierdzenie, iż pielgrzymem był każdy poeta odwiedzający Puławy. Gutschmidt, niczym wędrowiec oprowadza czytelników po malowniczym parku i zachwyca się otaczającą przyrodą:

Otaczają ten przepyszny pałac

Leśne wzgórza, zdobiąc go swoją zielenią,

Jak bujna fala ciemnych loków

Upiększa jeszcze lica delikatne,

A na lekko poruszonej toni

Witają mnie, drgającym obrazem, pałacu blanki.

Wynurzają się wyspy z młodymi krzewy,

Płyną nad nimi powiewy wieczoru (s. 27).

I dalej:

Jednak fantazja swoim letnim wzlotem

Wiedzie mnie na ojczyste niwy,

Podczas gdy fale wiślane mnie niosą,

Wracam chętnie do was myślą, Kochani,

Mili chroniący mojej młodości,

Do gór mojej Ojczyzny,

Której czoło wieńczy bór królewski.

Ze szczytów spoglądałem pełen tęsknoty

$\mathrm{Ku}$ dalekim, drogim horyzontom,

Ku rzece, co niegdyś szumiała mi chłodno,

$\mathrm{Ku}$ wesołej dolinie, na której pagórkach

Mnie świeżył soczysty owoc winorośli,

Gdzie drogi książę w duchu przodków

Włada Saksonią w duchu łagodności (s. 29).

Przytoczony opis tęsknoty do dalekiego kraju przypomina „kraj lat dziecinnych" Adama Mickiewicza, gdzie poeta-tułacz w Inwokacji do Pana Tadeusza wyraża tęsknotę do dalekiego kraju, do pagórków leśnych i zielonych łąk okala-

30 Christoph Gutschmidt, jak podaje TPP EWG. Aktu zgonu 95/1812 „Generał dywizji 23 wojska saskiego Księcia Warszawskiego [...] kawaler wielu orderów, umarł w domu J.O. Ks. Czartoryskiego. Monografia Cmentarzy Włostowickich w Puławach, red W.W. Bednarski, „TPP Studia Puławskie", Seria A, Zagadnienia społeczno-historyczne, t. 3 (5), Puławy 1990, s. 29-30, a także Puławski Stownik Biograficzny, red. H. Mącznik, Lublin 1994, s. 156. 
jących Niemen. Podobny ból i tęsknotę za dalekim krajem odczuwa Gutschmidt przybywający do Puław. Tutejsze krajobrazy przypominają mu ojczyznę, gdzie „ze szczytów spoglądał pełen tęsknoty, ku drogim horyzontom”. Zauroczony widokiem parku, nie wie, w którą stronę się udać, aby zwiedzić okolicę. Entuzjazm jest tak duży, że niepewny pielgrzym na miejsce pierwszej wędrówki wybiera pałac, opisując także starannie jego wnętrza.

Swój zachwyt puławskim ogrodem odkrywa przed czytelnikami również wychowanek Liceum Krzemienieckiego Karol Sienkiewicz ${ }^{31}$. Wiersz puławskiego bibliotekarza Ogród w Puławach staje się reminiscencją poety-pielgrzyma przechadzającego się po parku i dostrzegającego urok tego niebywałego miejsca. Podobnie, jak wszyscy poeci puławscy, zwraca uwagę na otaczającą go naturę i opisuje wrażenia, jakie w nim wywołuje. Drukowany w „Polihymnii” nakładem Jana Juliana Szczepańskiego tekst Sienkiewicza powstał z inspiracji utworami Woronicza i Niemcewicza, jednak poeta przedstawia swoją wizję ogrodu:

\footnotetext{
W ogrodzie ulubionym i Florze i oku,

W miłem Tobie siedlisku witaj nowy roku.

Witaj wiosno! Jak tylko twój pobyt nastaje,

Wnet zakwitną ogrody, zaśpiewają gaje;

Odmłodzi się natura, nieba się rozśmieją

Świat nowy nową pieści człowieka nadzieją,

A jak ten obraz słońca po wodach upływa,

Tak się w sercu maluje natura szczęśliwa,

I człowiek obce szczęście za swe szczęście bierze (s. 9).
}

Ulubiony ogród „Florze i oku” staje się miejscem przechadzek i spacerów, gdzie można oddać się kontemplacji. Samotna wędrówka wśród drzew i kwiatów jawi się jako przyroda budząca się do życia. „Błękit nieba zdobiąca zieloność gałęzi” staje się zaś miejscem wiecznej szczęśliwości, gdzie z niedowierzaniem można podziwiać wiosenny krajobraz. Ogród porównany do wiosny może napawać wspomnieniami minionej przeszłości. Przechadzka po ogrodzie to nie tylko fascynacja parkiem otaczającym pałac. Przedmiotem kontemplacji stają się również przyległe tereny, wliczone do zespołu pałacowo-parkowego. Puławscy poeci opisują znajdującą się po drugiej stronie łachy Kępę, miejsce spotkań i zabaw towarzyskich, farmę na Żulikach, włostowicki cmentarz czy okoliczne wsie ${ }^{32}$.

Przytoczony fragment jest jedną z nielicznych relacji opisujących przyległe wioski i tereny zagospodarowane przez księżną. Zmierzający do parku mógł podziwiać liczne ogródki założone przez twórczynię puławskiego parku. Tym sa-

31 R. Przybylski, Krzemieniec: Opowiesśc o rozsądku zwyciężonych, Warszawa 2003; J. Skowronek, Karol Sienkiewicz, [w:] Polski Stownik Biograficzny, t. 37/4, z. 155, Wrocław-Kraków 1997, s. 222-226.

32 W relacji epistolarnej August Kretowicz napisze: „Gdzie bądź z resztą oko się obróci Puławy zdają się być Rajem ziemskim. Objechaliśmy wsie: Włostowie, Puławską, Purchatkę, a wszędzie zdumieni i uradowani byliśmy zarazem. Wsie te są najpiękniej zbudowane, mają żywe płoty, szpalery dla cieni, przed domami ogródki z najlepszymi rodzajami drzew owocowych staraniem księżnej zakładane. Idem, Puławy, Lwów 1831, s. 42-43. 
mym fascynacja wiejskimi chatami i przylegającymi do nich ogródkami przygotowywała wędrującego poetę do ich kontemplowania. Motyw wędrówki stał się wyznacznikiem poezji romantycznej, która, jak twierdził Lichaczow, korzystała z kinetycznych możliwości opisu ${ }^{33}$. Poeta u progu romantyzmu nie opisywał wspaniałych widoków z jednego stałego, nieruchomego i niezmiennego punktu widokowego. Na pierwszy plan zaczął się wysuwać czynnik ruchu i poeta, który wrażenia $\mathrm{z}$ opisywanych widoków relacjonuje z perspektywy spacerującego po parku pielgrzyma. Człowiek stawał się małą istotą i na tle majestatycznej przyrody przyjmował postawę kontemplacyjną ${ }^{34}$, odnajdując w niej pierwiastek boskości. Celem zaś była wspomniana już wcześniej samotna wędrówka. Przytoczony fragment utworu K. Sienkiewicza:

Trzykroć ogród przebiegam i zawsze mi się zdaje,

Choć wszystkie kwiaty przejrzał, wszystkie ścieżki przebył

Żem jeszcze nic nie widział, jeszcze nigdzie nie był.

Raz do mego obrazu, gdy myśl rozpościeram,

Te ogrody, te góry i te niebo zbieram;

Drugi raz zapomniawszy o ziemi, o świecie,

Wielkim się cudom wiosny w jednym widzę kwiecie.

Ileż ja ich tu widzę!!... Ogrodzie bogaty! (s. 10)

U Gutschmidta zaś:

Już zmierzch wieczorny na dół spływa,

A ja powoli stąpam przez gaj cichy

Ścieżką krętą, jakbym się obawiał

Natury uroczystą zakłócić godzinę (s. 73).

Wizja niemcewiczowska, również jawi się jako samotna wędrówka:

Rzucam gmachy wesołe, idę rozrzewniony [...]

Zanurzony w dumaniu przechodzę do kępy

Wiekuistych topoli odwiedzam ostępy,

Siadam, myślę, znów zwracam kroki me powolne (IV, 41, 46).

Występujące w przytoczonych fragmentach czasowniki ruchu mają za zadanie podkreślić znaczenie czynności podziwiającego ogród. Tak oto podmiot liryczny mówi: „przebiegam”, „zmierzam”, „stąpam”, „myśl rozpościeram”, „zbieram”, „rzucam”, „idę”, „, przechodzę”, „odwiedzam”, „siadam”, „zwracam kroki”. Deskrypcja opisywanych wrażeń jawi się tutaj jako możliwość podziwiania krajobrazów współistniejącą z możliwością naturalnej, nieskrępowanej swobody ruchu. Znaczenia więc nabywa wspomniana już wcześniej kinetyka.

Pozostając w temacie przyrody, choć nie jest to celem artykułu, należy dodać, iż uczestnik ogrodowych przechadzek oddawał się także zabawie, jako homo ludens ${ }^{35}$ uczestnicząc w wszelakich jej formach. Jednak w miarę upływu

33 D. Lichaczow, op. cit., s. 236.

34 A. Kowalczykowa, Pejzaż romantyczny, [w:] Biblioteka romantyczna, red. M. Janion, Warszawa 1980, s. 15.

35 J. Huizinga, Homo ludens. Zabawa jako źródło kultury, Warszawa 1998. 
lat zaczęto upatrywać w ogrodzie miejsca, gdzie na łonie dzikiej natury można swobodnie oddawać się medytacji czy kontemplacji. Poeta stawał się tym samym ogrodnikiem malującym i podziwiającym swoje dzieło. Kreacja rzeczywistości, jaką tworzył w nim, nabierała często cech odwołujących się do tradycji, kultury czy symboliki ogrodowej. W opozycji do stworzonego przez Johana Huizingę pojęcia homo ludens można stwierdzić, iż człowiek-poeta przebywający na łonie przyrody stawał się niejako człowiekiem twórczym - homo fa$b e r^{36}$ - ogrodnikiem, który na kartach dzieła kreuje naturę. J. Maleszyńska trafnie stwierdza, że:

Praca ogrodnika nad fragmentem natury, czyli to, co rzeczywiste w metaforze, oraz wydzielanie przez ogrodnika niezwykłej przestrzeni w naturze, czyli to, co metaforyczne w zwykłych działaniach — począwszy od genezyjskiego mitu towarzyszą sobie niezmiennie ${ }^{37}$.

Pisząc swoje dzieło, poeta staje się twórcą wyobraźni ogrodowej kreowanej przez kontemplację i reminiscencję. W nadwiślańskiej rezydencji istniał kult twórczości księdza Delille’a, a w szczególności jego dzieła o ogrodach, w którym poeta umieścił fragment dotyczący puławskiego parku ${ }^{38}$. Propagatorką poezji księdza była Izabela Czartoryska, dzięki której można było doczekać się tłumaczeń Les Jardins dokonanych przez Franciszka Karpińskiego ${ }^{39}$. Mimo iż poeta nigdy nie był w Puławach, to nakreślił wspaniałą relację z widoków wraz z opisem parkowych budowli. Tym samym stał się niejako ogrodnikiem tworzącym ogrodową rzeczywistość w wykreowanym przez siebie świecie.

O, czyż zdołam zapomnieć waszą okazałość,

Wy, których wdzięk z bogactwem zgodną tworzy całość,

Wy, o szczęsne Puławy, którym bogi w darze

Dały wszystkich powabów odległych miraże. [...]

Zaś, ja, pól malarz, który, ufny w swe rzemiosło,

Roi, iż żyć da dziełu, co wam w rękach rosło,

Me imię, w głazie ryte, mieszka tu — choć imię,

Dumne ze spojrzeń waszych, na łąk tych kilimie! [...]

Czytając me nazwisko, odbite w strumieniu.

$\mathrm{O}$, czemuż nic milczenia głazu nie rozkruszy!

Pieśń niósłby wam w podzięce, a dla czułej duszy

Jakież struny targane ręką umiejętną

Wdzięcznego naśladować serca mogą tętno? ${ }^{40}$

36 Ibidem, s. 7.

37 J. Maleszyńska, op. cit., s. 16.

38 A. Aleksandrowicz, Jacques Dellile w ogrodach puławskich, „Annales UMCS” IV, 4, sec. FF, 1986.

39 F. Karpiński, Ogrody i poema L'abbe Dellile'a napisane i z francuskiego przettumaczone w 1783 roku, [w:] Dzieła F. Karpińskiego wierszem i proza, t. 3, Warszawa 1806.

40 Fragment przetłumaczył z francuskiego M.M. Poznański, Ogrody, „Kurier Warszawski” 1935, nr 235, s. 9. 
W przytoczonym fragmencie piewca ogrodów odtwarza z dokładnością to, co nakreśliła mu w listach księżna Izabela oraz wyraża podziękowanie dla tej, która postawiła mu pomnik pośród lip. Poeta wyznaczał ponadto kanon, jakim kierowali się puławscy literaci. Po części ten styl narzucała również sama księżna. $\mathrm{W}$ istocie poeci puławscy wchodzili niejako w kompetencje artystów malarzy, oddając dokładny opis parku wraz z gamą kolorów i barw o różnych porach dnia. Odwoływali się do tez postawionych w Les Jardins, w których oprócz kinetycznych możliwości opisu przyrody dominującą rolę odgrywały zmysły na przykład słuchu czy wzroku.

Ten, który po ogrodzie spaceruje, — jak zauważa Zofia Rejman — daje się bezwolnie powodować zmysłowi wzroku, pociągają go coraz to nowe elementy krajobrazu, tak jakby uderzające piękno puławskiego parku, ze smakiem umieszczone w nim pomniki i głazy przytłumiły na chwilę logikę i rozwagę poety, zamiast „odczytywać znaki”, próbuje językiem poezji oddawać wrażenie, jakie czyni na nim malarskie piękno krajobrazu ${ }^{41}$.

Inspirację z Delille'a czerpał wspomniany Gutschmidt opowiadający się za jego twórczością. Wskazuje na to już sentencja zamieszczona na pierwszej stronie:

Tu przede mną szybuje Dellile, poeta uroczy,

Przez naturę do sztuk piękny zapalony,

On uczcił prześliczne Puławy

Pieśnią przednią we frakońskim języku.

A dziś nowicjusz poezji w mistrza idąc ślady

Puławy także niemiecką pieśnią sławi,

Własnemu jednak nie dowierza dziełu (s. 183).

„Malarz pól” stał się inspiracją i wzorem dla poetów piszących o puławskim parku. Wyznaczał ponadto kanon, jakim kierowali się literaci przebywający na dworze Czartoryskich. Poniekąd ten styl narzucała sama księżna.

Sztuka ogrodowa oddziaływała na uczucia odbiorców, w czym dużą rolę odgrywały ekspresywne formy inspiracji ${ }^{42}$. Ogród wpływał także na emocje wynikające z obserwacji natury i zmian, jakie w niej zachodzą. Wrażenia introspekcji wyrażane były wieloma uczuciami wpływającymi na doznania odbiorcy. L.G. Jakobs wymienia między innymi „uczucia, których dostarcza wpływ czystego powietrza, uczucia wywołane spokojnym, spodziewanym spacerem albo odpoczynkiem, uczucia estetyczne pobudzone widokiem krajobrazu naturalnego, uczucia estetyczne dostarczane sztuką spowodowanymi zmianami i upiększeniami w owym krajobrazie"43. Najpełniej wyraziły się one w twórczości ogrodowej Niemcewicza. Przytoczone poniżej opisy krajobrazu puławskiego oddają pełną gamę kolorów występujących w parku. Poeta przechodząc, dostrzega „zielone smugi”, „ciemne lip sklepienia” oraz widzi „bielące się i błyszczące szkarłaty”:

41 Z. Rejman, Jan Pawet Woronicz. Poeta i kaptan, Chotomów 1992, s. 33.

42 D. Lichaczow, op. cit., s. 204.

43 L.G. Jakobs, O wytwornym ogrodnictwie, cyt. za: D. Lichaczow, op. cit., s. 205. 
Zielone smugi, ciemne lip sklepienia,

Przez które światło drze się pośród cienia,

I zamiast dawniej spod sznura ciągniętych

Drzew przymuszonych, dziś w kształtach zagiętych

Wśród błonia klomby nieładem rzucone.

Tam niskie krzewy, topole wzniesione,

Drobne rośliny, barwiste ich szaty

Bielą się, płonią lub błyszczą szkarłaty.

Cóż gdy te gaje słońce swym promieniem

Na poły złoci, resztę kryje cieniem? [...]

$\mathrm{Na}$ darni w ciemno zarosłym chodniku

Między klonami, wśród świateł przesmyku

Lekkich muszlinów postrzegasz miganie (I, w. 119-151).

Poeta przytacza opis parku o poranku, kiedy towarzyszy mu bogactwo kolorów i dźwięków oraz różnorakich barw i doznań emocjonalno-zmysłowych. Dostrzegamy tu także grę świateł i cieni. Niczym malarz oddaje realia oglądanego krajobrazu, w którym pod wpływem wschodzącego słońca budzi się do życia otaczająca przyroda. Bogactwo opisów nasuwa stwierdzenie, iż takie przedstawienie wizji ogrodu staje się wynikiem wnikliwej obserwacji przyrody o różnych porach dnia. Można stwierdzić, choć nie jest to do końca trafne, iż opisy krajobrazu wzbudzają w czytelnikach wrażenia impresjonistyczne: o różnych porach dnia można oglądać jeden $i$ ten sam przedmiot, jakim jest opisywany przez poetę ogród. Nocą natomiast, jak zauważył Piotr Żbikowski, przeważają wrażenia zmysłowe: wzrok, węch i słuch ${ }^{44}$. Przytoczmy fragment:

Co za luba spokojność w tym ogrodzie ciemnym!

Jak te kwiaty wokoło zapachem przyjemnym

Napełniają powietrze, Zefir, co mnie chłodzi,

Rozpędza czarne myśli i serce łagodzi

Słowik w pieniach miłosną duszę swą wyziewa,

A powstający księżyc srebrny blask rozlewa (III, w. 893-898).

Podobnie jak w utworach romantycznych poetów, twórczość poetycka Niemcewicza wyraża uwrażliwienie na ruch, świat barw i kolorów. Wrażenia, jakich doznaje podmiot liryczny nocą, odbierane są przez zmysły. Poeta-ogrodnik przez sensualny charakter widzenia świata natury wpływa na kształt swojego dzieła, natomiast ogród zmienia się w tekst kultury. Tym samym przez sensualny charakter dzieła przyroda staje się częścią osobowości poety. Dmitrij Lichaczow chyba słusznie zauważył, iż „Malowniczość ogrodów pejzażowych dawała ogromne szanse rozwoju indywidualnych gustów i aluzję do wyrażenia w materiale przyrodniczym uczuć ludzkich, a także do zlania się przyrody z osobowością

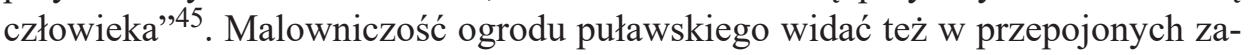

${ }^{44}$ P. Żbikowski. Opisy przyrody w poezji Niemcewicza z początków XIX wieku jako zwiastuny literackiego przełomu, [w:] Julian Ursyn Niemcewicz - pisarz, historyk, świadek epoki, red. J. Wójcicki, Warszawa 2002, s. 203.

45 D. Lichaczow, op. cit., s. 202. 
chwytem i nostalgią do kraju lat dziecinnych wersach Gutschmidta. Poeta również jest pod wrażeniem widoku parku w letnią noc.

I za ostatnim blaskiem purpurowej zorzy

Idzie fala fiołkowych woni.

Księżyca promienie lśnią z powierzchni wód, [...]

Czy to sen radosnych nocy letnich,

Czy szybko powiódł mnie do celu tęsknoty?

Jak drzemiącego, którego dźwięki harfy

Wybawiają ze swobodnego królestwa snów

I nie wie jeszcze, czy dźwięczą mu głosy ziemi

Czy głosy aniołów;

Zwlekam z radowaniem się jawą (s. 27-28).

Przedstawiony obraz puławskiego parku implikuje doznania zmysłowe podmiotu lirycznego, który dzięki charakterystycznym zjawiskom odzwierciedla myślenie artysty. W opisie, podobnie jak u Niemcewicza, przeważają gamy barw i odgłosów wydawanych przez naturę nocą, co jeszcze bardziej potęguje odbieranie widoków zmysłami. Romantyczny opis zespolony grą dźwięków nocy i barwami widzianych obiektów nasuwa stwierdzenie, iż jest to kierunek zmierzający do odkrycia nowej epoki zapowiadającej romantyzm, w którym ogród zaczął inspirować artystów poprzez swą tajemniczość i grę zmysłów. Jak zauważył Lichaczow: „Poeci doby romantyzmu umiłowali iluzoryczność życia przyrody, przejawiającą się w takich zjawiskach jak odbicia na powierzchni wód, ścieląca się mgła, cienie, rosa, zachód słońca, poświata księżycowa, sen czy drzemka"46. Przytoczmy jeszcze fragment opisu ogrodu Karola Sienkiewicza:

Tak dumałem; już słońca uchylone promienie,

Żegnając się z ogrodem przedłużały cienie,

Już słowik czekał w liściu wieczornej cichości,

Gdy drzwi wrzaskliwe nowych ogłosiły gości.

Weszły... zmienił się ogród, na ogród Adama,

Zadumiały się kwiaty, nawet wiosna sama.

Ścieżki się zaludniły wdziękami ziemianek.

Zadawało się, ze wieczór zmieniał się w poranek.

Ileż są tu piękności, ile wdzięków mieści (s. 14).

Poeta widzi ogród także o różnych porach dnia, począwszy od oglądania go poranną porą, a skończywszy wieczorem. Wrażenia impresjonistyczne sprawiają, iż nie potrafi on powiedzieć, $\mathrm{w}$ jakim momencie doby przebywał $\mathrm{w}$ ogrodzie. Miejsce to staje się dla literata ogrodem Adama, w którym możliwa jest pełna realizacja doznań zmysłowych podkreślających związek człowieka z naturą. W przytoczonym opisie również pojawia się wspomniana gra barw i świateł.

Koncepcja założeń parkowych przejawiała się w różnorakich zespołach symboli i archetypów literackich. Poeci przebywający w puławskim ogrodzie upatry-

46 Ibidem, s. 241. 
wali w nim przede wszystkim miejsca szczęśliwego, odnajdywali w nim także wiele znaków. Ich twórczość odnosiła się w dużej mierze do kultu drzew i kwiatów ${ }^{47}$. Poszukiwano w nim też koncepcji patriotycznych i historycznych, nawiązujących do sytuacji politycznej w kraju po utracie niepodległości ${ }^{48}$. Szczególną uwagę poświęcano również zmysłom słuchu. W przyrodzie poszukiwano nie tylko emocjonalnego zespolenia się z nią poprzez doznania wizualne. W przytoczonych powyżej fragmentach czytelnik dostrzeże też dźwięki przyrody. To zarówno śpiew słowika, jak i „szemranie wód”, ,poruszona toń” czy „szumiąca rzeka”. Ruchy powietrza i wody stały się tym samym wyznacznikiem poezji ogrodowej powstającej u progu romantyzmu. Ważnym elementem stała się także możliwość oglądania zachodzących w przyrodzie zmian, możliwość patrzenia na przyrodę jak na widowisko i wyłaniania się własnych refleksji. Wedle słów Michała Radziwiłła: „dla człowieka, który umie patrzeć, wszystko jest widowiskiem w naturze. I najmniejszy szczegół pobudza jego refleksję"49. Przy szerszym potraktowaniu tematu należałoby bliżej przyjrzeć się twórczości poetów z kręgu puławskiego, a w szczególności literaturze ogrodowej. Wspomniany poemat Puławy Juliana Ursyna Niemcewicza dostarcza historykom literatury nie tylko informacji o puławskim ośrodku. W opiniach wielu badaczy wskazywano w nim na liczne innowacje zapowiadające nową epokę ${ }^{50}$. Większej uwagi wymaga natomiast prześledzenie poematu Errinerungen an Pulawy, który śmiało wpisuje się w literaturę romantyczną ${ }^{51}$.

Poeci u progu romantyzmu szukali w ogrodowej przechadzce naturocentrycznego stosunku do otaczających ich krajobrazów. Wędrowca interesowała dzika i nieujarzmiona przyroda, która żyje, a jej codzienność wyznaczały cykliczne zmiany doby czy pór roku. Przebywający w ogrodzie „czytali” przyrodę za pomocą zmysłów, upatrując $\mathrm{w}$ niej boskiego wtajemniczenia czy wejścia w nią. Doznania emocjonalne były zaś wynikiem procesów psychologicznych zachodzących w umyśle wędrowca, utożsamianych ze stanem wewnętrznego życia

47 A. Aleksandrowicz, Z problematyki kultu drzew w poezji Kniaźnina, cz. I, „Annales UMCS” V, 6, sec. FF, 1987.

48 A. Aleksandrowicz, W ogrodzie wolności, [w:] Wyobraźnia epok dawnych. Obrazy — tematy — idee, red. J.K. Goliński, Bydgoszcz 2001, s. 377-400.

49 M. Radziwiłl, Arkadiana. Z papierów ostatniej wojewodziny wileńskiej, Heleny z Przeździeckich ks. Radziwiłłowej, „Przegląd Polski” 1885, z. XI-XII, [za:] L. Komarnicki, Sztuka ogrodnicza na przełomie w. XVIII i XIX, Warszawa 1923, s. 218.

50 J. Kallenbach w objaśnieniach do twórczości Niemcewicza napisał, iż: „Na owe czasy była to najśmielsza rewolucja poetycka, a komu trudno na prędce zdać sobie z niej sprawę, niech po kolei odczyta parę wstępów to z Zofijówki, to z Świątyni Sybilli, [...] a zrozumie, że w granicach poezji opisowej zamknąć można utwory bliskie sobie czasem powstania, ale jakże dalekie duchem, co je wywołał". J.U. Niemcewicz, Puławy..., s. 8.

51 Postawionej przeze mnie tezie przyświeca fakt, iż Gutschmidt opatrzył swoje dzieło sentencjami zaczerpniętymi między innymi z Adama Mickiewicza czy Johanna Wolfganga Goethego. Fragmenty dzieł romantyków stają się poniekąd inspiracją i tematem do jego własnych refleksji. 
poety $^{52}$. Twórczość puławskich poetów współdziałała z programem, jaki narzucała na swym dworze księżna Izabela Czartoryska. Propagowany przez nią model ogrodów angielskich znalazł swe odzwierciedlenie w literaturze ogrodowej. Podsumowując powyższe rozważania, musimy posłużyć się stwierdzeniem Agnieszki Whelan, które w pełni zakwalifikować można również do rozważań na temat symboliki ogrodowej:

Park nie był wyłącznie kreacją historyczno-patriotyczną, lecz zawierał różnorodne treści i wręcz zapraszał do wielu sposobów zachowań. Te z kolei wpływały na sposób, w jaki o Puławach rozmawiano i pisano, czyli na to, jaka była sława Puław ${ }^{53}$.

Sława Puław i ogrodu zapowiada przełom romantyczny z całym jego ukrytym systemem znaków i komponentów ogrodowych, które należy odczytać i przelać na papier.

\title{
Literary visions of Princess Izabela Czartoryska's garden as exemplified by the semantics of feelings - Romantic perception of a wandering poet
}

\author{
Summary
}

In the article the author attempts to capture the first signs of the Romantic turn, using as her example the semantics of feelings of a poet in a garden. She analyses fragments of poems describing Princess Izabela Czartoryska's park, including Puławy by Julian Ursyn Niemcewicz and Erinnerungen an Pulawy by Eugen von Gutschmidt. She points to those signs of the Enlightenment-Romanticism turn that were associated with poetic perception and emerged as a result of observations of nature during lonely wanderings. In addition, the author focuses on the role of the wanderer, who not only sees nature through the senses receiving external stimuli, but who also makes the surrounding reality the object of his observations. She tries to demonstrate that on the threshold of Romanticism the poet pays attention to the movement, light, sound and colours of the garden scenery surrounding him. In her view the poets praising the Puławy gardens recognised the nature of the layout and Czartoryska's concept according to which certain meanings and associations were to be read on the basis of the symbolism of the garden word. The Puławy gardens seen through the eyes of strollers appeared as a series of signs and components that were to be decoded and interpreted. The author concludes that the oeuvre of poets from the Puławy circle gave rise to changes in the thinking about and interpreting of the surrounding reality and that the whole cycle of transformations is also a result of psychological processes occurring in the wanderer's mind. Their interpretation makes it possible to say that an attempt to capture the signs of the new era is a long-term processes. The changes were not rapid; they resulted not only from observations of nature but also from the loss of national independence.

52 D. Lichaczow, op. cit., s. 210.

53 A. Whelan, Czy Puławy byty sławne? Percepcje i sady rodzime i obce, [w:] Międzynarodowa Konferencja Naukowa. Ogrody rezydencji magnackich XVIII-XIX ww. w Europie Środkowej i Wschodniej oraz problemy ich ochrony. Ogrody Czartoryskich. Studia i Materiały, Humań, 9-13 lipca 2000 r., „Ogrody” 10 (16), 2001, s. 37. 